\title{
Fenomena Remaja Menggunakan Media Sosial dalam Membentuk Identitas
}

\author{
Oleh: Primada Qurrota Ayun \\ Dosen Ilmu Komunikasi, Fakultas Ilmu Sosial dan Ilmu Politik, \\ Universitas Diponegoro, Semarang. \\ E-mail; primadaqa.ayu@gmail.com
}

\begin{abstract}
The Internet and teens are the two things are interrelated. Survey from the Ministry of Communications and Information in Indonesia showed that the largest internet usage is to access social media. In Indonesia, the phenomenon of young people in using social media is quite interesting to study. Teens build their self-identity to obtain the image they want and express private problem into a social media issues raised in this study. The theory used in this research is the Social Identity Theory, Symbolic Interaction and Media Ecology. This study is a qualitative study using phenomenological method. Results from this study showed that adolescents show identity vary in their social media and they express personal problems in social media, but in the form implied.
\end{abstract}

Keywords: Social Media, Teens, Identity.

\section{A. Pendahuluan}

Perkembangan teknologi informasi dan komunikasi telah merubah cara interaksi individu dengan individu yang lain. Internet menjadi sebuah ruang digital baru yang menciptakan sebuah ruang kultural. Tidak dapat dihindari bahwa keberadaan internet meberikan banyak kemudahan kepada penggunanya. Beragam akses terhadap informasi dan hiburan dari berbagai penjuru dunia dapat dicari melalui internet. Internet menembus batas dimensi kehidupan pengguna, waktu, dan ruang, yang dapat diakses oleh siapapun, kapanpun, dan dimanapun.

Keberadaan internet secara tidak langsung menghasilkan sebuah generasi yang baru, yaitu generasi $n e(x t)$. Generasi ini dipandang menjadi sebuah generasi masa depan yang diasuh dan dibesarkan dalam lingkungan budaya baru media digital yang interaktif, yang berwatak menyendiri (desosialisasi), berkomunikasi secara personal, melek komputer, dibesarkan dengan videogames, dan lebih banyak waktu luang untuk mendengarkan radio dan televisi (Ibrahim, 2011: 310).

Terjadi pergeseran budaya, dari budaya media tradisional yang berubah menjadi budaya media yang digital. Salah satu media sosial yang cukup berpengaruh di Indonesia adalah Facebook. Pada tahun 2009, Koran Kompas (dalam Ibrahim, 2011: 312) menyatakan bahwa pengguna Facebook di Indonesia mencapai 11 juta orang. Keberadaan media sosial telah mengubah bagaimana akses terhadap teknologi digital berjaringan.

Media sosial merupakan salah satu bentuk dari perkembangan internet. Data dari Kementerian Komunikasi dan Informatika (Kemenkominfo) tahun 2013 (kominfo.com), mengungkapkan pengguna internet di Indonesia saat ini mencapai 63 juta orang. Dari 
angka tersebut, 95 persennya menggunakan internet untuk mengakses jejaring sosial. Panji (2014), menyatakan terdapat tiga motivasi bagi anak dan remaja untuk mengakses internet yaitu untuk mencari informasi, terhubung dengan teman (lama dan baru) dan untuk hiburan. Pencarian informasi yng dilakukan sering didorong oleh tugas-tugas sekolah, sedangkan penggunaan media sosial dan konten hiburan di dorong oleh kebutuhan pribadi.

Penggunaan media sosial di kalangan remaja pada saat ini merupakan sesuatu yang tidak dapat dihindari lagi. Hampir setiap hari remaja mengakses media sosial hanya untuk sekedar mencari informasi melalui twitter, kemudian menyampaikan kegiatan yang mereka lakukan melalui facebook atau path. Hasil dari survey yang dilakukan oleh Kementrian Kominfo (Suara Merdeka, 27 Maret 2015), menunjukkan 5 media sosial terpopuler di Indonesia, yaitu Facebook dengan 65 juta pengguna, Twitter 19,5 juta pengguna, Google+ 3,4 juta pengguna, LinkedIn 1 juta pengguna, dan Path 700 juta pengguna.

CEO Twitter, Dick Costolo menyebut Indonesia sebagai salah satu pengguna daring (online) terbesar di dunia. Dia menambahkan dengan adanya Twitter membuat masyarakat Indonesia pada saat ini menyadari apa yang sedang terjadi, saling memberikan informasi yang bermanfaat. Anak muda Indonesia mampu menggunakan industry kreatifnya dan menggunakan Twitter untuk hal-hal positif. "Keuntungan Twitter adalah semakin banyak pengguna semakin banyak yang dapat mengonfirmasi rumor yang ada", Dick Costolo (Suara Merdeka, 27 Maret 2015).

Berbeda dengan Twitter, yang mengandalkan pesan singkat 150 karakter, Path hadir dengan membawa fitur media sosial yang lain. Lebih personal, namun keberadaan Path sebagai salah satu media sosial di Indonesia cukup menarik perhatian. CEO Path sekaligus pendiri, Dave Morin (dalam Desyana, 2015:1) mengklaim bahwa Indonesia adalah pengguna path nomor pertama di Indonesia. Meski baru diluncurkan pada November 2010, jejaring sosial ini meraup banyak pengguna. Jumlah pengguna di Indonesia saat ini sudah meraup jumlah pengguna lebih dari 4 juta.

Path merupakan media sosial yang menarik karena pada mulanya path merupakan sebuah aplikasi media sosial yang sifatnya pribadi. Misalnya berbagi momen special bersama keluarga, teman, atau sahabat. Tapi ternyata di Indonesia sendiri pengguna path menjadikan sebagai aplikasi privat maupun publik. Pengguna path di Indonesia mendapat dan berbagi informasi melalui fitur repath (Tunggaldjaja, 2015:1).

Kehadiran media path di kalangan remaja menjadi suatu fenomena yang menarik. Seperti yang kita ketahui, bahwa keberadaan internet di Indonesia paling banyak di akses oleh remaja. Studi yang dilakukan oleh UNICEF dengan Kominfo, The Berkman Center for Internet and Society, dan Harvard University yang melakukan survei nasional mengenai penggunaan dan tingkah laku internet para remaja, menunjukkan bahwa setidaknya 30 juta orang remaja di Indonesia yang mengakses internet secara regular, itu berarti hampir setengahnya adalah remaja (Lukman, 2014).

Kehadiran media sosial di kalangan remaja, membuat ruang privat seseorang melebur dengan ruang publik. Terjadi pergeseran budaya di kalangan remaja, para remaja tidak segan-segan mengupload segala kegiatan pribadinya untuk disampaikan kepada teman-temannya melalui akun media sosial dalam membentuk identitas diri mereka. Penelitian ini ingin mendeskripsikan bagaimana media sosial digunakan remaja sebagai sebuah media untuk membentuk identitas diri. 
Diterbitkan oleh Program Studi IImu Komunikasi

Universitas Ahmad Dahlan Yogyakarta

\section{B. Kajian Teoritis}

\section{Identitas}

Identitas, merupakan sebuah hal yang penting di dalam suatu masyarakat yang memiliki banyak anggota. Identitas membuat suatu gambaran mengenai seseorang, melalui; penampilan fisik, ciri ras, warna kulit, bahasa yang digunakan, penilaian diri, dan faktor persepsi yang lain, yang semuanya digunakan dalam mengkonstruksi identitas budaya. Identitas menurut Klap (Berger, 2010: 125) meliputi segala hal pada seseorang yang dapat menyatakan secara sah dan dapat dipercaya tentang dirinya sendiri - statusnya, nama, kepribadian, dan masa lalunya.

Gudykunst (2002: 225), menyatakan bahwa identitas merupakan hal yang penting dalam sebuah komunikasi budaya. Konsep identitas juga dapat dilihat dari aspek budaya (Tingtoo-mey, dalam Gudykunst, 2002: 214) yang didefinisikan sebagai emotional signifikan, yang membuat seseorang dilekatkan pada suatu hal, yang membedakannya dengan orang lain sehingga lebih mudah untuk dikenal.

Social Identity Theory (SIT) menurut Tajfel \& Turner (Gudykunst, 2002: 225) bertujuan bahwa individu memiliki sebuah konsep pada dirinya sendiri dalam bersosialisasi dan mengidentifikasi dirinya sendiri. Identitas personal melihat bahwa individu adalah sebuah makhluk yang unik, memiliki budaya, hidup di dalam sebuah group, dan identitas sosial mengacu pada pengetahuan dalam anggota kelompok budaya dan berkomunikasi dengan budaya yang lain. Karakteristik individu yang dipengaruhi oleh kolektivistik dalam komunikasi individu:

- Personality Orientations (orientasi personal), menggambarkan bagaimana orientasi personal dalam berhubungan atau berkomunikasi dengan orang lain.

- Individual Values (nilai-nilai individu), merupakan nilai-nilai personality yang dimiliki oleh Individu dalam mempertahankan dan menjaga kepercayaan diri seseorang ketika melakukan komunikasi.

- Self Constractuals (penyingkapan diri/ ekspresi diri), menggambarkan bagaimana individu menggekspresikan dirinya ketika berkomunikasi dengan individu yang lain.

Fokus utama di dalam teori ini adalah melihat bagaimana identitas merupakan suatu hal yang diproduksi dalam kategori sosial (Hogg, 1993; Hogg \& Abraham, 1988; Turner 1991, dalam Gudykunst, 2002: 259). Kategori sosial bisa berupa etnisitas, jender, dan afiliasi politik, sebagai bagian dalam struktur sosial. Individu termasuk bagian dalam kategori sosial dan pada dasarnya adalah anggota dalam kategori sosial tersebut. Identitas menghubungkan antara individu dengan masyarakat melalui anggota suatu kelompok yang mempengaruhi kepercayaan individu, perilaku, dan pengetahuan dalam hubungan mereka dengan anggota dari kelompok sosial yang lain.

Dalam perspektif komunikasi, identitas tidak dihasilkan secara sendiri, melainkan dihasilkan melalui proses komunikasi dengan yang lain. Prinsip utama di dalam identitas muncul ketika sebuah pesan berubah di antara dua orang. Identitas dapat dinegosiasikan, diperkuat, dan dirubah dalam suatu proses komunikasi. Tujuan dari identitas ini adalah menjadikan dan membangun sebuah komunikasi. 


\section{Interaksi Simbolik}

Teori interaksi simbolik merupakan sebuah cara berpikir mengenai pikiran, diri, dan masyarakat. George Herbert Mead (dalam Morissan dkk, 2010: 126), memahami interaksi simbolik sebagai interaksi di antara manusia, baik secara verbal maupun nonverbal untuk memunculkan suatu makna. Dengan adanya aksi dan respon dari individu yang lain, secara tidak langsung kita memberikan makna ke dalam kata-kata atau tindakan yang ada.

Hal yang mendasar di dalam teori ini adalah pentingnya makna dalam perilaku manusia, pentingnya konsep diri, dan hubungan antara individu dengan masyarakat. Mead (dalam Morissan dkk, 2010: 128-133) mengemukakan tiga konsep penting di dalam teori ini yaitu;

1) Masyarakat

Masyarakat dalam pemikiran teori interaksi simbolik, terdiri atas perilaku yang saling bekerja sama di antara para anggotanya. Mead menyebut bahwa masyarakat terwujud atau terbentuk dengan adanya simbol-simbol berupa isyarat dari tubuh. Karena dengan adanya kemampuan manusia dalam mengucapkan simbol dan bertindak, serta merespon apa yang dihasilkan maka kita akan berempati dan mengambil peran mereka.

Di sini masyarakat merupakan sebuah jaringan interaksi sosial dimana anggota masyarakat memberikan makna terhadap tindakan mereka sendiri dan tindakan orang lain dengan menggunakan simbol. Keadaan saling mempengaruhi antara menanggapi orang lain dan menanggapi diri sendiri merupakan sebuah konsep penting di dalam teori ini.

2) Diri

Menurut paham dalam interaksi simbolik, individu berinteraksi dengan individu lainnya sehingga menghasilkan suatu ide tertentu mengenai diri. Sebuah teori yang mengungkapkan mengenai diri, bagaimana pengalaman berinteraksi dengan dengan orang lain. Dalam teori tentang diri ini, terdiri atas seperangkat elemen yang terdiri dari tiga dimensi.

"Dimensi pertama adalah dimensi menunjukkan (display), yaitu apakah aspek dari diri itu dapat ditunjukkan kepada pihak luar (public) atau merupakan sesuatu yang privat. "Dimensi kedua adalah realisasi atau sumber, yaitu tingkatan atau derajat pada bagian atau wilayah tertentu dari 'diri' yang dipercaya berasal dari dalam individu sendiri atau berasal dari luar. Elemen diri yang dipercaya berasal dari internal disebut dengan istilah individually realized, sedangkan elemen diri yang dipercaya berasal dari hubungan orang itu dengan kelompoknya disebut dengan collectively realized. Dimensi ketiga adalah disebut dengan agen, yaitu derajat atau tingkatan dari kekuatan aktif yang ditimbulkan oleh diri. Elemen aktif merupakan tindakan yang dilakukan orang, sedangkan elemen pasif adalah kebalikannya" (Morissan dkk, 2010: 136-137). 
Diterbitkan oleh Program Studi IImu Komunikasi

Universitas Ahmad Dahlan Yogyakarta

Teori mengenai diri membahas mengenai bagaimana kesadaran diri (self consciousness), dimana seseorang memikirkan dirinya sebagai suatu objek, yang berarti etika seseorang memikirkan dirinya ia menunjukkan kesadaran akan dirinya.

Kita memiliki diri karena kita dapat menanggapi diri kita sebagai suatu objek. Satu-satunya syarat agar sesuatu menjadi objek adalah dengan cara memberikannya nama dan menunjukkannya secara simbolik. Para remaja sering sekali memandang diri mereka dengan cara orang lain memandang mereka. Mereka akan menggunakan gambaran yang diberikan oleh orang lain kepada mereka melalui berbagai interaksi yang mereka lakukan dengan orang lain. Hal ini dapat dilakukan melalui proses pengambilan peran atau menggunakan perspektif orang lain dala, melihat diri kita, menuntun kita untuk memiliki konsep diri.

Konsep diri adalah keseluruhan persepsi kita mengenai cara orang lain melihat kita. Dimana seorang individu telah belajar untuk mengenal gambaran diri mereka melalui interaksi simbolik selama bertahun-tahun dengan individu yang berada di sekelilingnya. Orang-orang terdekat seperti orang tua, saudara, teman dekat, dan pacar adalah orang-orang yang sangat penting karena reaksi mereka akan berpengaruh terhadap pembentukan konsep diri seseorang.

Mead menambahkan bahwa diri memiliki dua sisi yang masing-masing memliki tugas penting, yaitu diri yang mewakili 'saya' sebagai subjek (I) dan 'saya' sebagai objek (me). Saya sebagai subjek adalah bagian dari diri saya yang bersifat menuruti dorongan hati, tidak teratur, tidak langsung, dan tidak dapat diperkirakan. Sedangkan saya sebagai objek adalah konsep diri yang terbentuk dari pola-pola yang teratur dan konsisten yang dipahami oleh individu dan dipahami oleh orang lain yang bersama dengannya.

3) Pikiran

Pikiran di dalam teori interaksi simbolik merupakan suatu proses dari kegiatan interaksi dengan diri anda sendiri. Kemampuan berinteraki yang berkembang bersama-sama dengan diri menjadi hal yang sangat penting bagi kehidupan manusia karena menjadi bagian dari setiap tindakan. Teori interaksi simbolik dalam artikel ini akan melihat bagaimana seorang individu berinteraksi dengan masyarakat dalam menyampaikan konsep dirinya melalui menampilkan kehidupan pribadi (ruang privat) ke dalam ruang publik.

\section{Ekologi Media}

Konvergensi media menghasilkan perubahan dalam arus informasi. Konvergensi media merupakan sebuah istilah yang mulai banyak digunakan sejak tahun 1990-an. Konvergensi menjadi suatu istilah yang umum dipakai dalam perkembangan teknologi digital, dimana di dalam konvergensi terjadi pengintergrasian teks, angka, gambar, video, dan suara dalam suatu media.

Fungsi dari konvergensi media oleh Miles (Flew, 2004:10) adalah sebagai informasi dan media yang meningkatkan proses pemikiran berdasarkan sistem teknologi 
berbasis komputer dan membawa pengguna media melintasi jaringan komunikasi. Sedangkan tujuan dari konvergensi adalah pencapaian suatu tujuan yaitu pengelolaan konten, baik berupa informasi, gambar, audio, dan lain-lain, agar dapat diakses masuk dalam jenis teknologi apapun sehingga dapat dikonsumsi oleh satu jenis atau berbagai jenis media. Adanya konvergensi media membuat khalayak bebas dalam mengakses, memproduksi, serta mengkonsumsi informasi.

Setiap jenis teknologi, melahirkan lingkungan teknologi. Lingkungan teknologi ini secara tidak langsung merubah kebudayaan, norma-norma sosial, pola-pola interaksi, dan organisasi-organisasi masyarakat", ungkap Tovler (Ibrahim, 1997). Ungkapan ini secara tidak langsung menjelaskan mengenai ungkapan McLuhan mengenai hubungan antara teknologi, media, dan masyarakat atau yang sering disebut dengan tehnological determinsm, yaitu paham bahwa teknologi bersifat determinan atau menentukan dalam membentuk kehidupan manusia.

Pemikiran McLuhan (West \& Turner, 2007) ini sering dinamakan teori mengenai ekologi media, dimana melihat lingkungan media, gagasan bahwa teknologi dan teknik, mode informasi dan kode komunikasi yang memainkan peran penting dalam kehidupan manusia. Asumsi dari teori ekologi media, yaitu (West \& Turner, 2007);

- Media mempengaruhi setiap perbuatan atau tindakan dalam masyarakat. Asumsi pertama ini menekankan pada gagasan pada saat ini manusia tidak dapat lepas dari media. Media merupakan sebuah hal yang penting, bahkan menembus ke dalam kehidupan manusia yang paling dalam. Keberadaan media memberikan pengaruh dalam kehidupan manusia dan masyarakat.

- Media memperbaiki persepsi dan mengelola pengalaman Asumsi kedua ini menjelaskan bagaimana manusia secara langsung dipengaruhi media. Dimana media memiliki kekuatan besar dalam mempengaruhi padangan kita terhadap dunia.

- Media mengikat dunia bersama-sama

Asumsi ketiga dari teori ekologi media menyebutkan bahwa media mengikat dunia bersama-sama. Untuk menjelaskan bagaimana media mengikat dunia menjadi satu sistem politik, ekonomi, sosial, dan budaya global, atau yang disebut dengan global village.

Kehadiran teknologi memberikan pengaruh sangat besar dalam kehidupan manusia. Manusia memiliki hubungan simbolik dengan teknologi, dimana kita menciptakan teknologi dan kemudian teknologi kembali pada siapa diri kita. Menurut McLuhan (Griffin, 2003), teknologi media telah menciptakan revolusi di tengah masyarakat karena masyarakat pada saat ini masyarakat sudah sangat tergantung kepada teknologi dan tatanan masyarakat terbentuk berdasarkan pada kemampuan masyarakat menggunakan teknologi.

Teknologi komunikasi menjadi penyebab utama perubahan budaya, McLuhan dan Innis (Morissan dkk, 2002: 31) menyatakan bahwa media merupakan kepanjangan atau eksistensi dari pikiran manusia, dengan demikian media memegang peran dominan dalam mempengaruhi tahapan perkembangan manusia. O'Brien (Bungin, 2006) mengatakan bahwa perilaku manusia dan teknologi memiliki interaksi di dalam lingkungan sosioteknologi. Sehingga bisa dikatakan bahwa ketika IT hadir dalam bentuk yang baru, 
Diterbitkan oleh Program Studi IImu Komunikasi

Universitas Ahmad Dahlan Yogyakarta

maka akan mempengaruhi struktur masyarakat, strategi komunikasi, masyarakat dan budaya, serta proses sosial. Kehadiran new media secara tidak langsung merubah struktur masyarakat Indonesia. Masyarakat Indonesia, bisa dikatakan menganut struktur sosial yang lama atau sering disebut tradisional.

Adanya pergeseran struktur sosial masyarakat secara tidak langsung mengubah pola komunikasi yang terjadi di dalam masyarakat tersebut. Saat ini remaja di Indonesia menjadi tidak segan dalam menyampaikan segala kegiatan pribadinya ke dalam ruang publik. Terjadi pergeseran budaya, mereka hidup dalam sebuah desa global dimana mereka mencoba untuk mengenal dan saling perduli dengan orang lain. Individu- individu di dalam masyarakat Indonesia, sekarang lebih aktif dalam membagi kisah kehidupan mereka melalui sosial media.

\section{Metode Riset}

Riset ini menggunakan analisis fenomenologi dari Von Eckartsberg (dalam Moustakas, 1994: 15-16). Langkah-langkah yang digunakan dalam penelitian fenomenologi ini adalah sebagai berikut:

1. Permasalahan dan perumusan pertanyaan penelitian. Peneliti berusaha untuk menggambarkan fokus penelitian dengan merumuskan pertanyaan dengan cara tertentu.

2. Data yang menghasilkan situasi, yaitu teks pengalaman kehidupan. Peneliti membuat narasi yang bersifat deskriptif yaitu menjabarkan hasil wawancara yang telah dilakukan.

3. Analisis data, berupa eksplikasi dan interpretasi. Setelah semua data terkumpul berdasarkan hasil wawancara, maka langkah terakhir yang harus dilakukan oleh peneliti adalah membaca dan meneliti dengan cermat data hasil wawancara untuk mengungkapkan konfigurasi makna, baik struktur maupun bagaimana makna tersebut diciptakan.

Subjek dalam penelitian ini adalah remaja yang aktif menggunakan media sosial dan memiliki akun media sosial facebook, twitter, dan path.

\section{Hasil Penelitian dan Pembahasan}

Moleong (2007: 13-14) menjelaskan bahwa pendekatan fenomenologi merupakan sebuah pandangan yang fokus terhadap pengalaman - pengalaman subjektif manusia. Hasil dan pembahasan dari pengalaman remaja menggunakan media sosial dalam membentuk identitas diri, sebagai berikut;

- Pengalaman para informan menggunakan Facebook dalam membentuk identitas diri.

Dalam menggunakan facebook, para informan secara tidak langsung membentuk identitas diri mereka melalui tiga gambaran, yaitu orientasi personal, nilai-nilai individu, 
dan ekspresi diri. Orientasi personal (Gudykunst, 2002: 225), menggambarkan bagaimana orientasi personal dari individu dalam berhubungan dan berkomunikasi dengan orang lain.

Melalui facebook, para informan mengakui bahwa mereka menggunakan media sosial facebook dikarenakan mereka terorientasi secara personal untuk berkomunikasi dan berhubungan dengan orang lain. Berikut merupakan kutipan dari beberapa alasan mengapa ketiga informan memutuskan untuk menggunakan facebook.

"Dulu itu gara-gara temen-temen pakai, ya udah ikutan. Jadi supaya enggak ketinggalan sama temen-temen. Misal pas lagi ngobrol tentang facebook, terus aku nggak punya kan kayak nggak balance". (Informan I)

"Kalau enggak salah sekitar kelas 2 SMA, mungkin sudah sekitar 5 tahun menggunakan facebook. Karena untuk kepentingan waktu paskib mbak. Temen-temen pada pakai, aku juga akhirnya buat facebook supaya bisa berkomunikasi”. (Informan II)

"Friendster sudah ditinggal, aku udah enggak punya temen lagi di friendster, terus pacarku juga buat facebook, yaudah aku buat facebook. Ngikutin tren mbak". (Informan III)

Dari hasil wawancara tersebut menunjukkan bahwa para informan secara tidak langsung memutuskan untuk memiliki media sosial facebook dikarenakan mereka tertarik secara personal untuk berkomunikasi dengan orang lain yaitu teman-teman mereka. Panji (2014), menyatakan terdapat tiga motivasi bagi anak dan remaja untuk mengakses internet yaitu untuk mencari informasi, terhubung dengan teman (lama dan baru) dan untuk hiburan. Dalam berhubungan dengan individu yang lain, para informan mengakui meski pada saat ini sudah jarang aktif dan mengupdate status di facebook, mereka masih menggunakan facebook hingga saat ini dikarenakan masih menjalin komunikasi dengan teman-teman mereka.

"Biasanya akses karena ada beberapa teman-teman yang kirim message, kayak undangan pameran githu mbak". (Informan I)

"Karena temen-temen SMA masih banyak yang pakai facebook. Jadi kayak ajang silaturahmi. Kemudian sama guru-guru SMA lewat facebook". (Informan II)

"Masih pakai facebook mungkin karena ya itu mbak, aku takutnya masih ada kebutuhan disitu. Misalnya waktu aku kerja, atau waktu nikah misalnya gitu. Soalnya kan ada banyak temen lama di facebook". (Informan III)

Nilai individu (Gudykunst, 2002: 225), merupakan nilai-nilai personaliti yang dimiliki oleh individu dalam mempertahankan dan menjaga kepercayaan diri seseorang ketika melakukan komunikasi. Dalam menggunakan media sosial facebook, para informan menampilkan nilai-nilai personal yang mereka miliki secara berbeda-beda. Mereka mengakui pada awal penggunaan mereka masih mengupdate masalah pribadi, tetapi pada 
Diterbitkan oleh Program Studi IImu Komunikasi

Universitas Ahmad Dahlan Yogyakarta

saat ini mereka sudah tidak mengupdate masalah pribadi atau mengupdate masalah tersebut secara tersirat.

"Kalau aku paling sering update status tentang bola, aku seneng banget sama Liverpol, terus sharing tentang musik juga. Eemm kalau galau kadang-kadang. Paling biasanya kalau habis nonton film, terus ada suatu quotes yang itu tu lagi aku banget. Jadi aku galaunya terselubung githu mbak". (Informan I)

"Kalau dulu waktu jaman SMA yang masih alay, kalau kuliah sekarang lebih ke proses pendewasaan jadi lebih ke sesuatu yang membuat motivasi diri aja. Kadang-kadang waktu membaca apa, ada quote yang menarik, aku langsung share lewat facebook". (Informan II)

"Kalau dulu ya menampilkan sebagai model. Karena dulu kan fotograferfotografer ngetag-ngetag foto ke aku. Waktu dulu aku belum pakai jilbab mbak. Rata-rata aku upload foto ulang dari fotografer, jadi fotoku bagus-bagus pada masa itu". (Informan III)

Dari kutipan wawancara tersebut, bisa dilihat bahwa nilai individu yang ditampilkan setiap informan berbeda-beda. Informan I, lebih sering menyajikan dirinya sebagai sosok yang gemar akan bola. Informan kedua, menyatakan saat ini ketika dia membuat status di facebook lebih kepada quote yang menarik, hal ini dikarenakan dia ingin menunjukkan bahwa sekarang dia sedang dalam proses pendewasaan diri. Sedangkan informan ketiga, mengaku dulu sering menampilkan sosok dirinya sebagai seorang model.

Nilai individu yang ditampilkan secara tidak langsung telah menggambarkan konsep diri. Dalam interaksi simbolik, individu berinteraksi dengan individu lainnya sehingga menghasilkan suatu ide tertentu mengenai diri. Konsep diri adalah keseluruhan persepsi kita mengenai cara orang lain melihat kita. Dimana seorang individu telah belajar untuk mengenal gambaran diri mereka melalui interaksi simbolik selama bertahun-tahun dengan individu yang berada di sekelilingnya.

Self Constractuals (penyingkapan diri/ ekspresi diri), dalam mengekspresikan diri informan memiliki cara ekspresi diri yang berbeda-beda.

"Aku lebih suka me-review film kalau di facebook. Suka sama Liverpol, suka musik juga. Soalnya kalau menampilkan kegalauan itu sukanya di ejekin sama temen mbak. Jadinya galau terselubung mbak. Kalau dulu waktu SMA pernah update masalah pribadi, tapi kalau sekarang masak masalah pribadi di-share mbak. Pernah ngeluh kalau lagi sakit lewat facebook, terus pernah juga jaman SMA update status pas lagi ribut sama cowok. Pernah juga update status buat nyindir temen. Itu jaman SMA sih mbak, kalau sekarang tuh lebih ke masak semuanya harus di-update". (Informan I)

"Sebenernya facebook juga bagi sebagian orang, merupakan penggambaran orang itu sebenernya. Karena facebook itu udah paling lama. Maksudnya, lebih kepenggambaran orang mau seperti apa ke depannya, kemudian karakternya juga terbaca dari aktivitas yang dilakukan di facebook. Yah harusnya lebih di 
pantau dan dikontrol saja, kalau pakai facebook karenakan media public". (Informan II)

"Kalau dulu ya menampilkan sebagai model. Karena dulu kan fotograferfotografer ngetag-ngetag foto ke aku. Waktu dulu aku belum pakai jilbab mbak. Rata-rata aku upload foto ulang dari fotografer, jadi fotoku bagus-bagus pada masa itu..... Ada aktivitasku juga di sekolah. Dulu aku paskib mbak. Jadi sisi lainku di luar pekerjaanku".

Dari hasil wawancara tersebut, dapat dilihat bahwa setiap informan memiliki cara penyingkapan diri yang berbeda-beda. Informan pertama dan kedua, cenderung lebih suka mereview film, musik, hobby, dan pernah mengupload masalah pribadinya. Mead (dalam Morissan dkk, 2010: 131) bahwa diri memiliki dua sisi yang masing-masing memiliki tugas penting, yaitu diri yang mewakili 'saya' sebagai subjek (I) dan 'saya' sebagai objek (me). Saya sebagai subjek adalah bagian dari diri saya yang bersifat menuruti dorongan hati, tidak teratur, tidak langsung, dan tidak dapat diperkirakan. Berbeda dengan informan ketiga, mereka lebih menampilkan sosok sebagai objek, dimana konsep diri yang terbentuk dari pola-pola yang teratur dan konsisten yang dipahami oleh individu dan dipahami oleh orang lain yang bersama dengannya.

- Pengalaman para informan menggunakan Twitter dalam membentuk identitas diri. Para informan secara tidak langsung membentuk identitas diri mereka melalui tiga gambaran, yaitu orientasi personal, nilai-nilai individu, dan ekspresi diri pada saat menggunakan twitter. Orientasi personal (Gudykunst, 2002: 225), menggambarkan orientasi individu dalam berhubungan dan berkomunikasi dengan orang lain.

"Twitter itu, pribadi. Lebih ke melihat tentang berita. Update status juga masih sering juga mbak dibanding dengan facebook. Dengan 140 kata, twitter itu suatu packaging yang pas menurutku mbak. Tidak terlalu banyak dan tidak terlalu sedikit. Kalau di facebook, orang itu bisa ngeshare panjang banget, kayak curhat malahan. Kalau twitter itu enggak". (Informan I)

"Kalau twitter karena karakternya sedikit, jadi lebih ke informasi aja sih mbak. Karena akses cepet. Informasinya update banget". (Informan II)

"Ya biasalah mbak, pertamanya gara-gara temen-temen. Kan kalau semua pada akses itu dan kita enggak punya kan jadi gimana gthu mbak. Jadi yaudah, ikutan bikin. Twitter itu aktif buat ngobrol sama temen sekelas. Ya padahal temen sekelas, tapi mention-mentionan lewat twitter. Kalau sekarang, paling cuma untuk lihat-lihat berita". (Informan III)

Hasil dari interview yang dilakukan dengan ketiga informan menunjukkan bahwa secara orientasi personal, twitter merupakan sebuah media sosial yang efektif untuk melihat informasi dan berita. Informan pertama menyatakan bahwa dia menganggap twitter merupakan sebuah media sosial yang bersifat pribadi, sehingga dia lebih nyaman update status di akun media ini. Informan kedua, menyatakan bahwa twitter lebih merupakan 
Diterbitkan oleh Program Studi IImu Komunikasi

Universitas Ahmad Dahlan Yogyakarta

sebuah media untuk memperoleh informasi. Sedangkan informan ketiga, memiliki jawaban yang berbeda. Dia merasa media ini cocok sebagai sebuah media untuk berkomunikasi bersama teman dan sebagai media untuk meng-update berita.

Dalam menjaga nilai-nilai personaliti yang dimiliki oleh Individu untuk mempertahankan dan menjaga kepercayaan diri seseorang ketika melakukan komunikasi, para informan memiliki respon yang bermacam-macam pada saat menampilkan nilai individu mereka.

"Kalau di twitter waktu update status lebih hati-hati. Mencitrakan dirinya lebih Smart sedikit. Belakangan ini masih sering update tentang pacar misalnya habis jalan atau masak sesuatu atau habis dikasih apa. Kalau yang aku update biasanya tentang kebahagiaan. Aku orangnya memang tidak bisa terbuka tentang masalah pribadi, nah sampai pada akhirnya ada masalah dengan pacar. Pacar aku selingkuh dan selingkuhannya nyindir aku di twitter. Ya akhirnya aku balas mbak, tetapi balasannya lewat sindiran. Aku mah orangnya kalau enggak disenggol duluan orangnya nggak bakal nyenggol'. (Informan I)

"Lebih menampilkan sosok yang fleksibel, apa adanya. Maksudnya enggak berlebihan juga. Sampai sekarang ya kadang masih ngetweet tentang masalah pribadi, tetapi dengan lebih bijak. Jadi bisa menggunakan bahasa dan diksi yang lebih baik". (Informan II)

"Kalau akhir-akhir ini, aku pengin dilihat sebagai sosok yang kalem saja. Karena awalnya dulu aku ramai banget di awal semester". (Informan III)

Citra diri berkaitan dengan adanya konsep diri. Mead (dalam Morissan, 2010: 130) menyatakan bahwa konsep diri adalah keseluruhan persepsi kita mengenai cara orang lain melihat kita. Dimana seorang individu telah belajar untuk mengenal gambaran diri mereka melalui interaksi simbolik selama bertahun-tahun dengan individu yang berada disekelilingnya. Para informan membangun konsep diri mereka sebagai sosok yang berbeda-beda di dalam media sosial twitter, dengan tujuan agar masyarakat sekitar mempercayai bagaimana diri mereka sebagai sosok yang hati-hati, fleksibel, ataupun kalem.

Tidak jauh berbeda dengan nilai individu yang ditampilkan, para informan juga memiliki keterbukaan yang berbeda-beda dalam media sosial twitter.

"Eksistensi diri kayaknya lebih kurang, karenakan kalau twitter lebih banyak text ketimbang share foto. Pernah sih share foto tentang liverpoll, nonton konser musik, pernah upload foto sama pacar, tapi enggak sedahsyat path kalau untuk ajang pamer atau eksistensi diri. Menurutku, twitter itu lebih ke tempat untuk sharing ide". (Informan I)

"Kalau biasanya update tentang aktivitas, perasaan, sesuatu yang singkat saja. Tapi bukan perasaan galau, lebih ke perasaan yang seneng. Pernah update tentang kekeselan sama temen. Lebih ekspresif mbak kalau di twitter". (Informan II) 
"Kalau di twitter, aku lebih random. Misalnya aku lagi kepikiran apa, ya udah aku tulis aja mbak. Soalnya aku di twitter lebih sering mention-mentionnan sama temen. Biasa saja". (Informan III)

Hasil dari wawancara menunjukkan bahwa para informan cukup terbuka menyatakan kegiatan pribadinya melalui twitter.

Ekspresi diri menggambarkan bagaimana individu menggekspresikan dirinya ketika berkomunikasi dengan individu yang lain. Para informan menjadikan dirinya sebaga 'saya', yaitu sebagai subjek yang bersifat menuruti dorongan hati, tidak teratur, tidak langsung, dan tidak dapat diperkirakan. Hal ini bertujuan agar tercipta komunikasi yang harmonis antara individu dengan lingkungannya. Mead (Morissan, 2010: 128) menambahkan bahwa masyarakat merupakan sebuah jaringan interaksi sosial dimana anggota masyarakat memberikan makna terhadap tindakan mereka sendiri dan tindakan orang lain dengan menggunakan simbol.

- Pengalaman para informan menggunakan Path dalam membentuk identitas diri Pengalaman para informan, ketika ditanya alasan mereka menggunakan media sosial path adalah karena teman-teman mereka menggunakan media sosial tersebut. Panji (2014), menyatakan terdapat tiga motivasi bagi anak dan remaja untuk mengakses internet yaitu untuk mencari informasi, terhubung dengan teman (lama dan baru) dan untuk hiburan. Orientasi personal dalam menggunakan path adalah karena keinginan untuk terhubung dan berkomunikasi dengan teman-teman mereka.

"Ya karena teman pakai, pacar pakai, yaudah pakai juga". (informan I)

"Alasan share ini, ya biar temen-temen tahu kalau Yusuf dikampus kadang enggak jelas, tapi ternyata Yusuf juga dengerin musik". (informan II)

"Awalnya ya karena temen-temen banyak. Terus abangku main itu, akhirnya ya ikut main. Temen-temen komunikasi banyak yang pakai, jadi yaudah pakai itu".(informan III)

Orientasi individu karena merasa terikat dengan teman-temannya, sesuai dengan asumsi dari teori ekolodi media. West \& Turner (2007), menyatakan bahwa media mempengaruhi perbuatan dan tindakan dalam suatu masyarakat, serta media mengikat dunia bersama-sama.

Nilai-nilai individu yang ditampilkan dalam media sosial ini cukup beragam. Ketiga informan mengakui senang men-share segala kegiatan yang sedang mereka lakukan melalui path dikarenakan fitur dalam media sosial ini memungkinkan untuk meng-update kegiatan mereka.

"Aku lebih sering foto waktu lagi jalan, atau aku habis masak apa nih, sesuatu yang menarik. Kalau di path lebih menampilkan apa yang lagi aku lakukan dan hal itu menarik, aku foto. Terus kalau enggak, foto atau sesuatu yang aku suka, 
Diterbitkan oleh Program Studi IImu Komunikasi

Universitas Ahmad Dahlan Yogyakarta

tempat yang aku suka, musik yang aku suka, film yang aku suka, lagi sama pacar, atau keluarga".

"Lebih ke penyaluran hobby. Share location misalnya. Karena di path itukan lebih banyak yang memakai sekarang, jadi kalau share location lebih banyak yang mengikuti. Misal sudah pernah ke sini, terus pada nanya oo kalau kesana gimana caranya. Sekarang travelling sudah bukan hobby jadi kayak lifestyle. Sehari saja bisa liburan ke Solo, kemana gthu mbak. Jadi saling share saja. Lebih ke tempat wisata mbak kalau aku". (Informan II)

"Dulu awal-awalnya random githu mbak, cuma waktu aku lagi galau ya buat kata-kata yang random. Misal waktu aku naik motor kepikiran pengin nulis sesuatu, sampai rumah langsung nulis sesuatu deh. Lebih ke mengekspresikan apa yang aku rasakan aja mbak. Random banget nulisnya. Lebih sering listening to dan foto. Kalau foto kan kesannya jadi anak yang aktif". (Informan III)

Hasil dari wawancara diatas menunjukkan bahwa remaja, menggunakan media sosial untuk menampilkan citra diri mereka, agar tampil seperti yang mereka harapkan. Peg Streep, (dalam Jatmika, 2013), menjelaskan bahwa salah satu alasan remaja menggunakan media sosial adalah untuk menumbuhkan citra. Oleh sebab itu, remaja menjadikan media sosial sebagai penumbuh citra positif mereka. Remaja akan cenderung memberikan kesan yang baik saat di media sosial. Mereka berharap orang lain melihat mereka seperti apa yang mereka harapkan.

Self constratuals dari para informan dalam menggunakan path, mereka menyatakan cukup terbuka di path. Ini dikarenakan mereka ingin menampilkan konsep diri mereka sebagai sosok yang ingin mereka citrakan. Hal tersebut sesuai dengan pengertian konsep diri adalah keseluruhan persepsi kita mengenai cara orang lain melihat kita (Morissan dkk, 2010: 130). Para informan mengakui bahwa path merupakan sebuah tempat yang cocok untuk ajang eksistensi diri mereka, meskipun mereka menyatakan tidak terlalu eksis seperti teman-teman yang lain yang mereka anggap eksis karena sering meng-update status di path.

"Kalau aku sih jarang, enggak eksis. Misal temen aku itu yang eksis itu bisa share location di tempat yang lagi eksis di semarang. Misalnya Yumee di pleburan. Satu orang kesana, dalam seminggu, temen-temen aku share location disana semua. Nah aku enggak kayak githu mbak... Intinya eksis menurutku adalah enggak mau ketinggalan, enggak mau dibilang enggak gaul. Kalau aku lebih menampilkan tentang my lovely life, bareng temen-temen dan keluarga". (Informan I)

"Kalau eksistensi di path menurut saya lebih share ke daily activity-nya. Menurut aku, sesuatu yang rutin dan berlebihan dan ditampilkan di path itu jadi sesuatu yang membosankan. Makanya kalau di path, eksis iya. Menampilkan hal sesuai karakternya tetapi jangan sering-sering juga".(Informan II)

"Menurutku eksis itu lebih ke aktif atau enggak-nya. Kalau aku menilai diriku sendiri ya aku aktif di media sosial, khususnya path dan instagram".(Informan III) 
Dari ketiga media sosial diatas para informan mengakui bahwa mereka pernah menyatakan atau menampilkan perasaan atau masalah pribadi melalui akun media tersebut baik secara tersurat ataupun tersirat. Informan pertama mengakui pernah mengungkapkan perasaannya menggunakan media sosial twitter.

"Jaman SMA pernah menampilkan perasaan.......Pacar aku selingkuh dan selingkuhannya nyindir aku di twitter. Ya akhirnya aku balas mbak, tetapi balasannya lewat sindiran. Aku mah orangnya kalau enggak disenggol duluan orangnya nggak bakal nyenggol".

Namun pada saat ini, informan pertama mengakui bahwa dia lebih berhati-hati untuk mengupload di twitter. Menurutnya twitter merupakan sebuah media sosial yang menuntut seseorang untuk lebih pintar.

"Kalau di twitter waktu update status lebih hati-hati. Mencitrakan dirinya lebih Smart sedikit".

Berbeda dengan informan kedua, dia mengakui pernah menyatakan permasalahan pribadinya melalui facebook pada saat SMA.

"Kalau sekarang sih sudah jarang, kalau dulu SMA ya galau-galau enggak jelas".

Saat ini, informan kedua juga masih menyatakan permasalahan pribadi secara tersirat melalui akun media path.

"Hmm... pernah, tapi lebih tersembunyi. Lewatnya lagu biasanya. Enggak langsung caption apa, lebih sering lewat lagu. Enggak to the poin, jadi biasanya pada tanya kenapa, terus bisa jawab enggak papa".

Sedangkan informan ketiga, mengakui hingga saat ini lebih sering menuliskan permasalahan pribadinya secara tersirat melalui twitter dan path. Hal ini menunjukkan bahwa keberadaan media sosial sebagai sarana untuk mendapatkan perhatian. Peg Streep, seorang pemerhati tren digital dan remaja (dalam Jatmika, 2013), menyatakan bahwa mendapat perhatian adalah dengan cara berbagai informasi menjadi kunci bagi mereka untuk mendapatkan perhatian bagi diri mereka sendiri. Mereka seringkali mengeluhkan tentang oversharing yang dilakukan pengguna media sosial lain. Padahal, mereka sendiri juga terjebak di dalamnya. Mereka berbagi begitu banyak hal (bahkan yang bersifat pribadi) di dalam media sosial.

\section{E. Kesimpulan}

Hasil penelitian mengenai fenomena remaja menggunakan media sosial dalam membentuk identitas diri mereka, menunjukkan bahwa ; 
Diterbitkan oleh Program Studi IImu Komunikasi

Universitas Ahmad Dahlan Yogyakarta

1. Remaja menunjukkan identitas diri yang berbeda-beda dalam ketiga akun media sosial tersebut.

2. Secara orientasi personal, para remaja menggunakan media sosial dikarenakan mereka ingin menjalin komunikasi dengan teman-teman mereka. Sehingga mereka memutuskan untuk memiliki akun media sosial lebih dari satu.

3. Nilai individu yang ditampilkan dalam media sosial, para remaja mencoba membuat sebuah citra positif tentang diri mereka di media sosial tersebut. Remaja suka menampilkan identitas mereka yang Smart, terlihat bahagia, dan suka menampilkan hobi atau kegiatan yang mereka sukai.

4. Para remaja cukup terbuka di media sosial dalam menunjukkan identitas mereka. Hal ini ditunjukkan dengan keterbukaan diri mereka melalui keinginan mereka untuk eksis dengan mengupload kegiatan yang sedang mereka lakukan (baik melalui foto ataupun status) dan mengungkapkan permasalahan pribadi di media sosial, dalam bentuk tersirat.

\section{Daftar Pustaka}

Berger, Arthur Asa, 2010, Pengantar Semiotika Tanda-Tanda Dalam Kebudayaan Kontemporer, Yogyakarta, Tiara Wacana.

Bungin, Burhan. 2006. Sosiologi Komunikasi: Teori, Paradigma, dan Diskursus Teknologi Komunikasi di Masyarakat. Kencana, Jakarta.

Desyana, Cornila. 2015. Path Klaim Paling Banyak Penggunaa di Indonesia.http://www.tempo. co/read/news/2014/02/24/061556984/PathKlaim-Paling-Banyak-Pengguna-di-Indonesia, Diakses tanggal 11 Maret 2015.

Flew, Terry. 2004. New Media. Oxford, Australia.

Griffin, E.M. 2003. A First Look at Communication Theory $5^{\text {th }}$ Edition. McGraw Hill, New York.

Gudykunst, William B dan Bella Mody, 2002, Handbook of International and Intercultural Communication 2nd Edition, United States of Amerika, Sage.

Ibrahim, Idi Subandy. 1997. Lifestyle Ecstasy: Kebudayaan Pop dalam Masyarakat Komoditas Indonesia. Jalasutra, Yogyakarta.

Ibrahim, Idi Subandy, 2011, Kritik Budaya Komunikasi, Yogyakarta, Jalasutra.

Jatmika, Aningtias. 2015. 4 Alasan Remaja Gemar Media Sosial.

http://tekno.tempo.co/read/news/2013/06/28/061491864/4-alasan-remaja-gemarmedia-sosial. diakses tgl 9 Juni 2015, jam 12.45

Kominfo.com, 2015. Pengguna Internet di Indonesia 63 Juta Orang. http://kominfo.go.id/index. $\mathrm{php} /$ content/detail/3415/Kominfo+\%3A+Pengguna+Internet+di+Indonesia+63+J uta+Orang/0/berita satker. Diakses tanggal 13 Maret 2015

Lukman, Enricko. 2014. Laporan 30 Juta Pengguna Internet di Indonesia adalah Remaja. http://id.techinasia.com/laporan-30-juta-pengguna-internet-di-indonesia-adalahremaja/ Diakses tanggal 11 Maret 2015. 
Morissan, dkk. 2010. Teori Komunikasi Massa. Bogor, Ghalia Indonesia.

Moleong, J.Lexy. 2007. Metode Penelitian Kualitatif. Bandung: PT. Remaja Rosdakarya

Panji, Aditya. 2014. Hasil Survei Pemakaian Internet Remaja Indonesia http://tekno.kompas.

com/read/2014/02/19/1623250/Hasil.Survei.Pemakaian.Internet.Remaja.In donesia.

Diakses tanggal 11 Maret 2015.

Suara Merdeka, 27 Maret 2015, Indonesia Pasar Paling Menguntungkan.

Tunggaldjaja, William. 2015. Unsur Privat dan Publik di Path.

http://www.koransindo.com/read /974299/152/unsur-privat-dan-publik-di-path1425952919

West, Richard dan Lynn H. Turner. 2007. Introducing Communication Theory. McGraw Hill. New York 